\title{
Melanoma of the Uvea pNO TNM Finding v7
}

National Cancer Institute

\section{Source}

National Cancer Institute. Melanoma of the Uvea pNO TNM Finding v7. NCI Thesaurus.

Code C88709.

Melanoma of the uvea with no regional lymph node metastasis. (from AJCC 7th Ed.) 